\title{
Boron adsorption in lowland soils from Paraná State, Brazil
}

\section{Adsorção de boro em solos de várzea do Estado do Paraná}

\author{
Fábio Steiner ${ }^{1 *}$; Maria do Carmo Lana²; Tiago Zoz ${ }^{1}$; \\ Rubens Fey²; Jucenei Fernando Frandoloso ${ }^{2}$
}

\begin{abstract}
Boron adsorption by soil is the main phenomenon that affects its availability to plants. This, the present study investigated the effect of liming on B adsorption by lowland soils of Paraná State, and to correlate these values with the physical and chemical properties of the soils. Surface samples of three lowland soils [Gleissolo Háplico (GX), Plintossolo Háplico (FX) and Cambissolo Háplico (CX)], with different origin material and physicochemical properties were used. Samples with or without liming application were incubated during 60 days. Boron adsorption was accomplished by shaking $4.0 \mathrm{~g}$ soil samples, for $24 \mathrm{~h}$, with $20 \mathrm{~mL}$ of $0.01 \mathrm{~mol} \mathrm{~L}^{-1} \mathrm{CaCl}_{2}$ solution containing different concentrations of $\mathrm{B}(0,1,2$, 4, 8 and $\left.16 \mathrm{mg} \mathrm{L}^{-1}\right)$. Sorption was fitted to non-linear form of the Langmuir adsorption isotherm. The adsorption isotherms indicated that the $\mathrm{B}$ adsorption increased with its increasing concentration in the equilibrium solution. Maximum adsorption capacity of B ranged from 3.0 to $13.9 \mathrm{mg} \mathrm{kg}^{-1}$ (without liming) and 14.7 to $35.7 \mathrm{mg} \mathrm{kg}^{-1}$ (with liming). Liming increased the amount of adsorbed B in Gleissolo Háplico and Plintossolo Háplico soils, although the bonding energy has decreased. The amount of adsorbed B by Cambissolo Háplico soil was not affected by liming application. The most important soil properties affecting the $\mathrm{B}$ adsorption in lowland soils were $\mathrm{pH}$, clay content, exchangeable aluminum and iron oxide contents.
\end{abstract}

Key words: Langmuir isotherm, maximum adsorption capacity of boron, liming, boron fertilizer

\section{Resumo}

A adsorção de boro (B) pelo solo é o principal fenômeno que afeta sua disponibilidade para as plantas. Este estudo teve por objetivo avaliar o efeito da calagem na adsorção de $\mathrm{B}$ em solos de várzea do Estado do Paraná, e correlacionar estes valores com os atributos químicos e físicos dos solos. Foram utilizadas amostras da camada superficial de 0-20 cm de três solos [Gleissolo Háplico (GX) argisolo, Plintossolo Háplico (FX) muito argiloso e Cambissolo Háplico (CX) de textura média], com diferente material de origem e propriedades físico-químicas. As amostras com ou sem calagem foram incubadas durante 60 dias. A adsorção de B foi realizada mediante agitação de $4,0 \mathrm{~g}$ de solo, durante $24 \mathrm{~h}$, com $20 \mathrm{~mL}$ de solução de $\mathrm{CaCl}_{2} 0,01 \mathrm{~mol} \mathrm{~L}^{-1}$ contendo diferentes concentrações de $\mathrm{B}\left(0,1,2,4,8\right.$ e $\left.16 \mathrm{mg} \mathrm{L}^{-1}\right)$. A sorção de $\mathrm{B}$ foi ajustada à forma não-linear da isotérmica de adsorção de Langmuir. As isotermas de adsorção indicaram que a adsorção de $\mathrm{B}$ aumentou com o aumento da sua concentração na solução de equilíbrio. A adsorção máxima de $\mathrm{B}$ variou de 3,0 a 13,9 mg kg-1 (sem calagem) e de 14,7 a 35,7 $\mathrm{g} \mathrm{kg}^{-1}$ (com calagem). A calagem aumentou a quantidade de B adsorvido nos solos argilosos, exceto no Cambissolo Háplico de textura média. As mais importantes propriedades do solo que afetam a adsorção B em solos de várzea do Estado do Paraná foram o $\mathrm{pH}$, e os teores de $\mathrm{Al}$ trocável, argila e óxidos de ferro.

Palavras-chave: Isoterma de langmuir, capacidade máxima de adsorção de boro, calagem, adubação boratada

\footnotetext{
${ }^{1}$ Pós-Graduandos em Agronomia. Dept ${ }^{\circ}$ de Produção Vegetal. Faculdade de Ciências Agronômicas, FCA. Universidade Estadual Paulista Júlio de Mesquita Filho, UNESP. Botucatu, SP. E-mail: fsteiner@ffca.unesp.br; tiagozoz@fca.unesp.br

2 Profs. do Centro de Ciências Agrárias, Universidade Estadual do Oeste do Paraná, UNIOESTE, Marechal Cândido Rondon, PR. E-mail: maria.lana@unioeste.br; rubensfey@hotmail.com; juceneiff@hotmail.com

* Author for corespondence
} 


\section{Introduction}

In humid areas, boron (B) deficiency in plants is often observed even though soils contain high total contents of B (XU et al., 2001). Such soils show a low B availability regardless of their total B content. Since the range of $\mathrm{B}$ soil solution concentrations between those causing deficiency or toxicity symptoms in plants is relatively narrow, prediction of B concentration in soil solution is particularly important. Such a prediction is usually based on the assumption that $\mathrm{B}$ adsorption-desorption is a reversible process and $\mathrm{B}$ distribution between solid and liquid phases at equilibrium can be described by an adsorption isotherm (SHAFIQ et al., 2008).

In soil, the B can be adsorbed by aluminum and iron oxides and their hydroxides (GOLDBERG, SUAREZ, SHOUSE, 2008; PRODROMOU, 2004), clay minerals (GOLDBERG; GLAUBIG, 1985), organic matter (ARORA; BHARDWAJ; SHARMA， 2002; YERMIYAHU; KEREN; CHEN, 1995) and calcium carbonate (SHAFIQ et al., 2008). The extent of B adsorption in soils depends on solution $\mathrm{pH}$, soil texture and mineral composition (COMMUNAR; KEREN, 2006). Of these, the $\mathrm{pH}$ has been reported as the main factor affecting the B adsorption in the soil (SALTALI et al., 2005; GOLDBERG, 1997; GOLDBERG; FORSTER; HEICK, 1993), mainly by influencing in the control of the predominant $\mathrm{B}$ species in solution and attributes related to its adsorption such as charge balance on colloids surface. Several possible mechanisms for the chemical combination of B with soils include anion exchange, precipitation of insoluble borates with sesquioxides, sorption of borate ions or molecular boric acid, formation of organic complexes, and fixation of $\mathrm{B}$ in the clay lattice (KEREN; BINGHAM, 1985).

Boron adsorption is highly influenced by $\mathrm{pH}$, increasing as the $\mathrm{pH}$ increases, attaining a maximum in $\mathrm{pH}$ around 9.0 and diminishing abruptly at high $\mathrm{pH}$ (GOLDBERG; CORWIN; SUAREZ, 2005). The maximum development of adsorption sites occurs at a $\mathrm{pH}$ equivalent to the dissociation constant ( $\mathrm{pKa}$ ) of boric acid, approximately 9.2. The agricultural practice that is most often used to raise soil $\mathrm{pH}$ is liming. Thus, it is expected that the acidity correction in soil until $\mathrm{pH}$ 6.0, as recommended for most crops, increases the $\mathrm{B}$ adsorption in the soil. In clayey Latosol of Mato Grosso State, Brazil, Rosolem and Bíscaro (2007) found that the application of $9.0 \mathrm{Mg} \mathrm{ha}^{-1}$ lime incorporated in the 0-20 cm layer increased seven times the maximum amount of adsorbed B in the first year. However, in lowland soils of southern Minas Gerais State, Brazil, Azevedo, Faquin and Fernandes (2001) found that liming decreases the maximum adsorption capacity of $\mathrm{B}$. These contradictory results indicate the need for more research to be conducted, particularly for lowland soils that vary widely in their physical, chemical and mineralogical characteristics, result of the origin material heterogeneity and the different levels of their hydromorphic state.

Thus, the present study investigated the effect of liming on B adsorption in three lowland soils of Paraná State, and to correlate these values with the physical and chemical properties of the soils.

\section{Material and Methods}

Surface samples from three lowland soils of Paraná State (designated GX, FX and CX) were selected by presenting a wide variation in the origin material (Table 1) and physical and chemical properties (Table 2). Soils were classified according to Embrapa (2006) and the physicochemical properties were determined by adopting standard procedures. Soil $\mathrm{pH}$ in water was determined potentiometrically in a 1:2.5 (soil:water) suspension using a combined calomel reference glass electrode and $\mathrm{pH}$ meter. Organic carbon was determined by Walkley-Black method. Hot water soluble B was extracted by the method of Abreu, Abreu and Andrade (2001). Basic cations $\left(\mathrm{Ca}^{2+}, \mathrm{Mg}^{2+}\right.$ and $\left.\mathrm{K}^{+}\right)$ were extracted by ion exchange resin and determined by flame atomic absorption spectrophotometry. 
Exchangeable $\mathrm{Al}$ was extracted by $1 \mathrm{~mol} \mathrm{~L}^{-1} \mathrm{KCl}$ solution and determined by titration with 0.025 mol L ${ }^{-1} \mathrm{NaOH}$. Cation exchange capacity (CEC) was estimated by the summation method (ECEC = $\mathrm{Ca}+\mathrm{Mg}+\mathrm{K}+\mathrm{Al})$. The Fe, $\mathrm{Al}$ and $\mathrm{Si}$ contents, associated to the secondary minerals, were extracted using $9 \mathrm{~mol} \mathrm{~L}^{-1} \mathrm{H}_{2} \mathrm{SO}_{4}$ (1:20 soil:solution ratio). Contents of $\mathrm{Fe}$ and $\mathrm{Al}$ were determined using flame atomic absorption spectrophotometry and $\mathrm{Si}$ by gravimetry, and expressed in the form of oxides to calculate the weathering index by the molar ratio $\mathrm{Ki}=\mathrm{SiO}_{2} / \mathrm{Al}_{2} \mathrm{O}_{3}$. Particle analysis was performed by the pipette method (EMBRAPA, 1997), based on decantation speed of different soil particles after dispersion in $0.015 \mathrm{~mol} \mathrm{~L}^{-1}\left(\mathrm{NaPO}_{3}\right)_{6} \cdot \mathrm{NaO} / 1 \mathrm{~mol}$ $\mathrm{L}^{-1} \mathrm{NaOH}$ by overnight shaking.

Table 1. Classification, origin material and sampling site of soil samples used in the study.

\begin{tabular}{cllll}
\hline Soil $^{(1)}$ & \multicolumn{1}{c}{ Description $^{(1)}$} & \multicolumn{1}{c}{ Origin material } & \multicolumn{1}{c}{ Sampling Municipality } & \multicolumn{1}{c}{ Texture } \\
\hline GX & Gleissolo Háplico & Basalt/alluvial sediments & Marechal Cândido Rondon & Clay \\
FX & Plintossolo Háplico & Shale & Ponta Grossa & Very clayey \\
CX & Cambisolo Háplico & Furnas sandstone & Ponta Grossa & Medium \\
\hline
\end{tabular}

(1) Brazilian classification as proposed by EMBRAPA (2006).

Source: Elaboration of the authors.

Table 2. Physical and chemical properties of the soils.

\begin{tabular}{|c|c|c|c|}
\hline \multirow{2}{*}{ Soil characteristics } & \multicolumn{3}{|c|}{ Soil $^{\dagger \dagger}$} \\
\hline & GX & FX & $\mathrm{CX}$ \\
\hline $\mathrm{pH} \mathrm{H} \mathrm{H}_{2} \mathrm{O}(1: 2.5)$ & 4.0 & 4.2 & 5.4 \\
\hline Clay $\left(\mathrm{g} \mathrm{kg}^{-1}\right)$ & 450.0 & 615.0 & 235.0 \\
\hline Sand $\left(\mathrm{g} \mathrm{kg}^{-1}\right)$ & 110.0 & 215.0 & 755.0 \\
\hline Organic C $\left(\mathrm{g} \mathrm{kg}^{-1}\right)$ & 7.1 & 10.3 & 9.4 \\
\hline Soluble B (mg kg$\left.{ }^{-1}\right)$ & 0.7 & 0.5 & 0.4 \\
\hline Exchangeable $\mathrm{Al}\left(\mathrm{mmol}_{\mathrm{c}} \mathrm{kg}^{-1}\right)$ & 35.0 & 12.0 & 1.0 \\
\hline $\mathrm{CEC}\left(\mathrm{mmol}_{\mathrm{c}} \mathrm{kg}^{-1}\right)^{\dagger}$ & 175.0 & 142.0 & 100.0 \\
\hline $\mathrm{SiO}_{2}\left(\mathrm{~g} \mathrm{~kg}^{-1}\right)$ & 161.0 & 114.0 & 43.0 \\
\hline $\mathrm{Fe}_{2} \mathrm{O}_{3}\left(\mathrm{~g} \mathrm{~kg}^{-1}\right)$ & 66.0 & 103.0 & 25.0 \\
\hline $\mathrm{Al}_{2} \mathrm{O}_{3}\left(\mathrm{~g} \mathrm{~kg}^{-1}\right)$ & 83.0 & 289.0 & 137.0 \\
\hline $\mathrm{Ki}^{*}$ & 3.3 & 0.7 & 0.5 \\
\hline $\mathrm{Kr} *$ & 2.2 & 0.6 & 0.5 \\
\hline
\end{tabular}

$\uparrow$ CEC: cation exchange capacity.

$\star \mathrm{Ki}$ : weathering index calculated by the molar ratio $\mathrm{SiO}_{2} / \mathrm{Al}_{2} \mathrm{O}_{3}$.

林 $\mathrm{Kr}$ : molar ratio $\mathrm{SiO}_{2} / \mathrm{Al}_{2} \mathrm{O}_{3}+\mathrm{Fe}_{2} \mathrm{O}_{3}(\mathrm{Kr}>0.75$ indicates kaolinitic soils; $\mathrm{Kr} \leq 0.75$ indicates oxidic soils).

${ }^{\dagger} \mathrm{GX}=$ Gleissolo Háplico. FX = Plintossolo Háplico. CX = Cambissolo Háplico.

Source: Elaboration of the authors. 
To evaluate the effect of liming on B adsorption, soil subsamples were incubated until constant $\mathrm{pH}$ (about 60 days) after receiving the application of calcium carbonate amount equivalent to increase the base saturation to $70 \%$. After this period, soil samples were air dried and ground to pass through a $2 \mathrm{~mm}$ mesh screen. The doses of calcium carbonate applied for the GX, FX and CX soils were 3.35, 4.35 and $1.05 \mathrm{~g} \mathrm{~kg}^{-1}$, respectively.

In the adsorption study was employed the method of Okazaki and Chao (1968), using a modification of $\mathrm{B}$ concentrations for the range $0-16$ mg L ${ }^{-1}$ (ALLEONI; CAMARGO, 2000). These concentrations were also used by Pavan and Correa (1988) in soils of Paraná State, Brazil, and it seems adequate for representing the element contents in solution for Brazilian soils.

To determine the amount of adsorbed B, $4.0 \mathrm{~g}$ of air-dried soil was shaken, in polyethylene tubes, for 24 hours at $24 \pm 2{ }^{\circ} \mathrm{C}$, with $20 \mathrm{~mL} 0.01 \mathrm{~mol} \mathrm{~L}^{-1}$ $\mathrm{CaCl}_{2}$ solution containing $\mathrm{B}$ concentrations of 0,1 , 2, 4, 8 and $16 \mathrm{mg} \mathrm{L}^{-1}$ as boric acid. This process was repeated thrice for each soil. After shaking, the soil solution was filtered through Whatman No 42 filter paper (VALLADARES; PEREIRA; ALVES, 1998). Boron concentration in the filtrate was determined by the Azomethine-H method using a spectrophotometer at $420 \mathrm{~nm}$ wave length as described by Abreu, Abreu and Andrade (2001).

The quantity of $\mathrm{B}$ adsorbed, $[\mathrm{B}]_{\mathrm{ads}}$, and the adsorption percentage, $\% \mathrm{~B}_{\text {ads }}$, were calculated by the following ratios, respectively:

$$
\begin{gathered}
{[\mathrm{B}]_{\mathrm{ads}}=\left[\left(\mathrm{C}_{0}-\mathrm{C}_{\mathrm{eq}}\right) \mathrm{V}\right] / \mathrm{m}} \\
\% \mathrm{~B}_{\mathrm{ads}}=\left[\left(\mathrm{C}_{0}-\mathrm{C}_{\mathrm{eq}}\right) / \mathrm{C}_{0}\right] \times 100
\end{gathered}
$$

where $[\mathrm{B}]_{\mathrm{ads}}$ is the quantity of adsorbed $\mathrm{B}$ after equilibrium (mg B kg-1 soil); $\mathrm{C}_{0}$ and $\mathrm{C}_{\mathrm{eq}}$ are the initial added and equilibrium concentrations ( $\mathrm{mg} \mathrm{B}$ $\left.\mathrm{L}^{-1}\right)$, respectively; $\mathrm{V}$ is the solution volume $(\mathrm{mL})$; and $\mathrm{m}$ is mass of the soil sample $(\mathrm{g})$. The quantity of B originally present in soil samples (Table 2), although small, was discounted in the calculation of the quantity of adsorbed B.

Adsorption isotherms ([B] $]_{\mathrm{ads}}$ vs. $\mathrm{C}_{\mathrm{eq}}$ ) were fitted from the experimental results, and the $\mathrm{B}$ adsorption was compared with that estimated by the non-linear form of the Langmuir isotherm:

$$
\mathrm{B}_{\text {ads }}=\left(\mathrm{K}_{\mathrm{L}} \mathrm{C}_{\text {eq }} \mathrm{Ads}_{\text {max }}\right) /\left(1+\mathrm{K}_{\mathrm{L}} \mathrm{C}_{\text {eq }}\right)
$$

where $\mathrm{K}_{\mathrm{L}}$ is the constant related to bonding energy of $\mathrm{B}$ to the soil $\left(\mathrm{L} \mathrm{mg}^{-1}\right)$ and $\mathrm{Ads}_{\text {max }}$ is the maximum adsorption capacity of soil (mg B kg-1 soil). Langmuir isotherm was fitted to the $\mathrm{B}$ adsorption results by the Fitfunc program (BARROW, 1987), which uses the non-linear optimization of the least squares and does not require the linearization of the isotherm, that avoids both the introduction of changes in the error distribution and the acquisition of influenced parameters $\left(\mathrm{K}_{\mathrm{L}}\right.$ and $\left.\mathrm{Ads}_{\text {max }}\right)$ (SOARES; ALLEONI; CASAGRANDE, 2005; GOLDBERG; FORSTER; HEICK, 1993).

The experiment was designed to be completely randomized. The efect of liming on maximum adsorption capacity of $\mathrm{B}\left(\mathrm{Ads}_{\max }\right)$ and bonding energy of $B$ to the soil $\left(\mathrm{K}_{\mathrm{L}}\right)$ were compared by $\mathrm{F}$ test at the 0.05 level of confidence. Comparison among soils was made based on the maximum adsorption values. Simple linear correlation analysis was performed to detect the physical and chemical properties of soil that correlated with the constant of Langmuir adsorption Ads $_{\max }$ and $\mathrm{K}_{\mathrm{L}}$ ) and adsorption after addition of $2.0 \mathrm{mg} \mathrm{L}^{-1} \mathrm{~B}$ (ALLEONI; CAMARGO, 2000).

\section{Results and Discussion}

The Langmuir model (hyperbolic Langmuir adsorption isotherms) fits well to the values of adsorbed B in the soil samples with and without liming, across the range of $\mathrm{B}$ concentrations (Figure $1)$, due to high determination coefficients $\left(R^{2} \geq 0.98\right)$. These results were expected since there is no 
record of deviations from the Langmuir equation at concentrations below $30 \mathrm{mg} \mathrm{L}^{-1} \mathrm{~B}$ (ALLEONI; CAMARGO, 2000). According to Alleoni, Camargo and Casagrande (1998), the use of lower concentrations is best suited to represent the $\mathrm{B}$ amount contained in Brazilian soils. These authors whilst investigating weathered Brazilian soils used $\mathrm{B}$ concentrations in the solution ranging from 0 to $16 \mathrm{mg} \mathrm{L}^{-1}$ and found that the results of B adsorption in soils were well fitted by the Langmuir isotherm.
Other authors also pointed out the ability of the Langmuir isotherm to participate in the $\mathrm{B}$ adsorption by soils under conditions of low concentration (ARORA; CHAHAL, 2010; SHAFIQ et al., 2008; SOARES; CASAGRANDE; ALLEONI, 2008; HUSSAIN; GHAFOOR; MURTAZA, 2006; SOARES; ALLEONI; CASAGRANDE, 2005; ALLEONI; CAMARGO, 2000; VALLADARES, PEREIRA; ALVES, 1998).

Figure 1. Boron adsorption isotherms for the three lowland soils of Paraná State, with and without liming. **: $\mathrm{p}<0.01$.
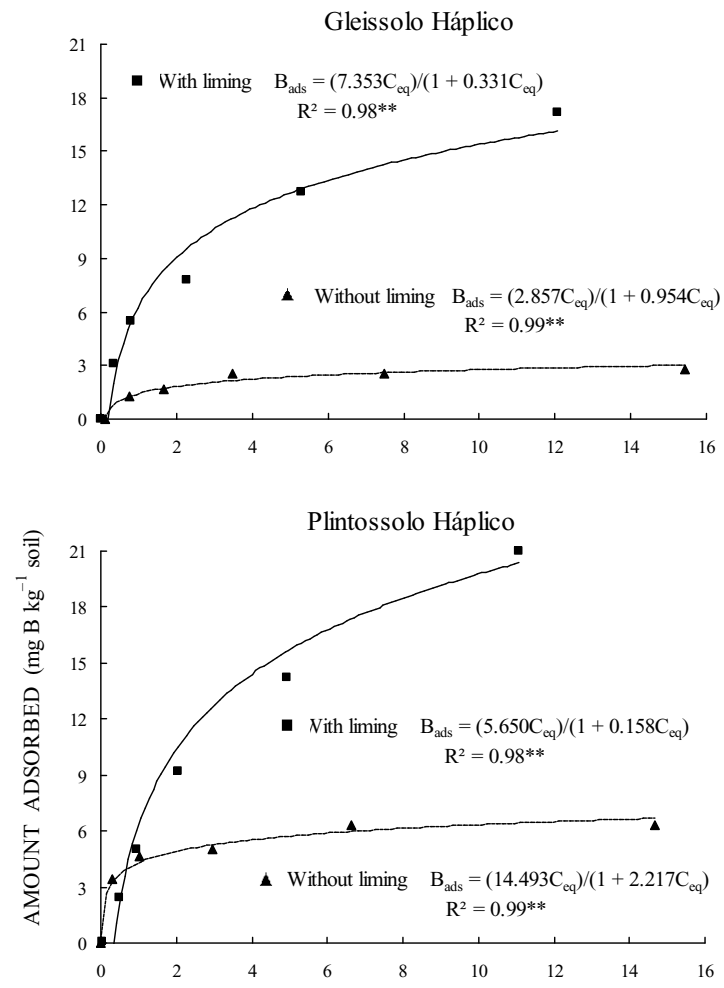

Cambissolo Háplico

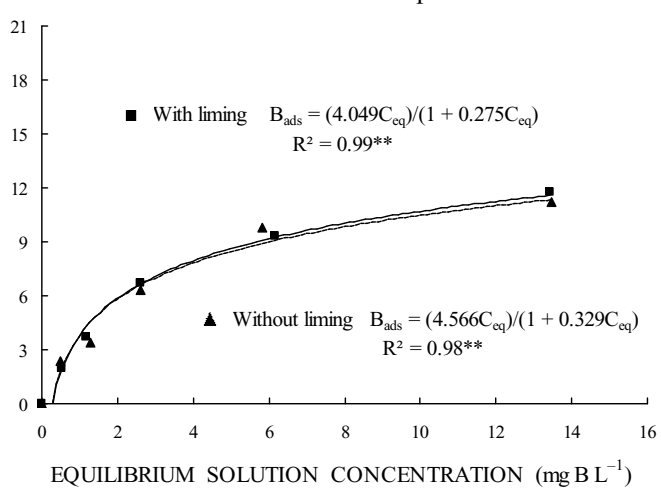

Source: Elaboration of the authors. 
Soil samples of Gleissolo Háplico (GX) and Plintossolo Háplico (FX) with liming, and samples of Cambissolo Háplico (CX) showed type H (Hight) of isotherm, according to the classification proposed by Giles, Smith and Huitson (1974), and used by several authors (SOARES; CASAGRANDE; ALLEONI, 2008; SOARES; ALLEONI; CASAGRANDE, 2005), which indicates the high adsorption affinity (Figure 1). In this type of curve, the number and energy of sites available for adsorption remain constant throughout the whole concentration range and expansion of the available surface area may occur in proportion to the amount adsorbed, until all the adsorption sites are occupied. This may be related to the appearance of new surfaces due to the precipitation of aluminum hydroxide after calcium carbonate addition (ALLEONI; CAMARGO, 2000). Soil samples GX and FX without liming showed isotherms of type L (Langmuir), with lower energy adsorption, characterized by low inclination due to the adsorption sites available decreasing as the adsorbent surface becomes saturated. From the absorption inclination, there was increase in B adsorption at lower concentrations. Most probably, with the increased B concentration, more sites were taken and the occurrence of the reaction was more difficult, decreasing the curve inclination (Figure 1). Valladares, Pereira and Alves (1998) found B adsorption isotherms type $\mathrm{H}$ for the lowland soils of Rio de Janeiro State, while Azevedo, Faquin and Fernandes (2001) found adsorption isotherms of types $\mathrm{L}$ and $\mathrm{H}$ for the lowland soils of Minas Gerais State, the latter when the $\mathrm{pH}$ was low.

The amounts of adsorbed $\mathrm{B}$ ranged from 1.3 to $11.2 \mathrm{mg} \mathrm{kg}^{-1}$ and 2.0 to $21.0 \mathrm{mg} \mathrm{kg}^{-1}$ in soils without and with liming, respectively (Figure 1), which are similar to the values normally found in the literature. For soils from São Paulo State, Alleoni and Camargo (2000), using the same B concentrations, found adsorbed B values from 0.6 to $11.1 \mathrm{mg} \mathrm{kg}^{-1}$ soil regardless of liming. Analyzing samples of clayey Latosol from a field experiment with liming, Rosolem and Bíscaro (2007) found maximum adsorbed $\mathrm{B}$ values between $9.5 \mathrm{mg} \mathrm{kg} \mathrm{g}^{-1}$ and $24.2 \mathrm{mg} \mathrm{kg}^{-1}$ after the first year of application of 1.5 and $9.0 \mathrm{Mg} \mathrm{ha}^{-1}$ lime. In the calcareous soils of Pakistan, Shafiq et al. (2008) found higher adsorbed B values from 5.5 to $108.0 \mathrm{mg} \mathrm{kg}^{-1}$.

The values of Langmuir constants (Table 3) were similar to those found in studies using a range similar to the B concentration added to the soil. The bonding energy of $B$ to the soil $\left(\mathrm{K}_{\mathrm{L}}\right)$ ranged from 0.16 to $2.22 \mathrm{~L} \mathrm{mg}^{-1}$, while the maximum adsorption capacity $\left(\mathrm{Ads}_{\max }\right.$ ) ranged from 3.0 to $35.7 \mathrm{mg} \mathrm{B} \mathrm{kg} \mathrm{kg}^{-1}$ soil. The wide variation in these parameters can be attributed to differences in the physical, chemical and mineralogical properties of the soils, in addition to the increase in $\mathrm{pH}$ after liming.

In highly weathered soils, Alleoni, Camargo and Casagrande (1998) and Alleoni and Camargo (2000) found lower $\mathrm{K}_{\mathrm{L}}$ values $\left(0.1-1.2 \mathrm{~L} \mathrm{mg}^{-1}\right.$ ) and $\mathrm{Ads}_{\max }\left(2.5-15.8 \mathrm{mg} \mathrm{kg}^{-1}\right)$, which in turn were very close to the results reported by Mezuman and Keren (1981) for Alfisols and Vertisols. However these were smaller than those that Soares, Casagrande and Alleoni (2008) found in the acric soils of São Paulo, who found $\mathrm{K}_{\mathrm{L}}$ values from 0.2 to $2.1 \mathrm{~L} \mathrm{mg}^{-1}$ and $\mathrm{Ads}_{\text {max }} 32.5$ to $128.6 \mathrm{mg} \mathrm{kg}^{-1}$. In the soils of Rio Grande do Sul, Brazil, Viezzer, Fráguas and Sinski (1995) found even higher values of $\mathrm{Ads}_{\max }$ B (71-416 mg B kg-1 soil). For some lowland soils of Rio de Janeiro and Minas Gerais, the Ads ${ }_{\text {max }}$ ranged from 6.1 to $10.3 \mathrm{mg} \mathrm{kg}^{-1}$ in the study of Valladares, Pereira and Alves (1998), and 14.7 to $30.9 \mathrm{mg} \mathrm{kg}^{-1}$ in the study of Azevedo, Faquin and Fernandes (2001). 
Table 3. Maximum adsorption capacity of $B\left(\mathrm{Ads}_{\max }\right)$, bonding energy of $\mathrm{B}$ to the soil $\left(\mathrm{K}_{\mathrm{L}}\right)$ and percentage of $\mathrm{B}$ adsorption (\%Ads) after addition of $2.0 \mathrm{mg} \mathrm{L}^{-1} \mathrm{~B}$ in three lowland soils of Paraná State with and without liming,

\begin{tabular}{|c|c|c|c|c|}
\hline \multirow{2}{*}{ Soil } & \multirow{2}{*}{ Liming } & \multicolumn{2}{|c|}{ Langmuir constants } & \multirow{2}{*}{$\%$ Ads } \\
\hline & & $\mathrm{Ads}_{\max }$ & $\mathrm{K}_{\mathrm{L}}$ & \\
\hline \multirow{3}{*}{$\begin{array}{l}\text { Gleissolo Háplico } \\
\text { (GX) }\end{array}$} & & $\mathrm{mg} \mathrm{B} \mathrm{kg}^{-1}$ soil & $\mathrm{L} \mathrm{mg}^{-1}$ & $\%$ \\
\hline & Without & $3.0 \mathrm{~b}$ & $0.95 \mathrm{a}$ & 17 \\
\hline & With & $22.2 \mathrm{a}$ & $0.33 \mathrm{~b}$ & 61 \\
\hline \multirow{2}{*}{$\begin{array}{l}\text { Plintossolo Háplico } \\
\text { (FX) }\end{array}$} & Without & $6.5 \mathrm{~b}$ & $2.22 \mathrm{a}$ & 38 \\
\hline & With & $35.7 \mathrm{a}$ & $0.16 \mathrm{~b}$ & 52 \\
\hline \multirow{2}{*}{$\begin{array}{l}\text { Cambissolo Háplico } \\
\text { (CX) }\end{array}$} & Without & $13.9 \mathrm{a}$ & $0.33 \mathrm{a}$ & 36 \\
\hline & With & $14.7 \mathrm{a}$ & $0.27 \mathrm{a}$ & 41 \\
\hline
\end{tabular}

Values represented by the different letters, for each soil show significant differences ( $\mathrm{F}$ test, $p<0.05$ ).

Source: Elaboration of the authors.

The highest values of maximum adsorption capacity estimated by the Langmuir model were obtained after liming application in the GX and FX soil samples (Table 3). Maximum adsorption ranged from 3.0 to $13.9 \mathrm{mg} \mathrm{kg}^{-1}$ (without liming) and from 14.7 to $35.7 \mathrm{mg} \mathrm{kg}^{-1}$ (with liming). Similarly, the percentage of B adsorption (\%Ads) measured after addition of $2.0 \mathrm{mg} \mathrm{L}^{-1}$ increased with liming (Table 3). Contrasting results were reported by Azevedo, Faquin and Fernandes (2001), working on four lowland soils in southern Minas Gerais, Brazil, who found decreased B adsorption capacity in all soils when lime was applied.

Liming resulted in an increased maximum adsorption capacity of B in the order of 86,82 and $5 \%$ for soils GX, FX and CX, respectively. A mean increase in the order of $33 \% \mathrm{~B}$ adsorption after application of calcium carbonate was observed in soil from São Paulo by Alleoni and Camargo (2000). The high maximum adsorption of $\mathrm{B}$ observed with the liming application in GX and FX soils is due to the fact that there is important B adsorption in aluminum hydroxides freshly precipitated after liming (PRODROMOU, 2004). Furthermore, another possible cause for the increase in adsorbed $\mathrm{B}$ is the binding of $\mathrm{B}$ with calcium carbonate. This can lead to the precipitation of calcium borate, the substitution of carbon for $\mathrm{B}$ in $\mathrm{CaCO}_{3}$ or $\mathrm{B}$ adsorption in $\mathrm{CaCO}_{3}$ (ALLEONI; CAMARGO, 2000).

In the calcareous soils of Pakistan, Shafiq et al. (2008) found that the maximum B adsorption in soil with a higher content of $\mathrm{CaCO}_{3}\left(128 \mathrm{~g} \mathrm{~kg}^{-1}\right)$ ranged from 8.4 to $108.4 \mathrm{mg} \mathrm{B} \mathrm{kg}^{-1}$ soil, while in soil with a lower content of $\mathrm{CaCO}_{3}\left(64 \mathrm{~g} \mathrm{~kg}^{-1}\right)$ it ranged from 7.5 to $47.0 \mathrm{mg} \mathrm{B} \mathrm{kg}^{-1}$ soil. However, Rosolem and Bíscaro (2007) found that even by applying relatively high doses of lime, the $\mathrm{B}$ adsorption by soil is only significant in the year that the liming was carried out, so that over time a greater amount of $\mathrm{B}$ remains in the soil solution under conditions of being readily absorbed by plants or even being lost by leaching. Similarly, Chen, Ho and Lee (2009) observed that soil re-acidification caused an increase in B desorption, increasing the element's content in solution. Indicating that B adsorption by soils submitted to liming is characterized by a rapid and reversible chemical reaction between the adsorbed and soluble B.

Another factor leading to an increased $\mathrm{Ad}_{\max }$ of $\mathrm{B}$ after liming is due to the increased $\mathrm{pH}$ of soil. Studies have shown that soil $\mathrm{pH}$ is one of the main factors affecting the availability of B in soils (GOLDBERG; FORSTER; HEICK, 1993; GOLDBERG, 1997). 
The adsorption of $\mathrm{B}$ increases in the $\mathrm{pH}$ range between 3 and 9, and decreases in the range of 10 to 11.5 , giving a typical bell curve with an absorption peak of about 9.0, very close to the boric acid $\mathrm{pKa}$ of 9.2 (GOLDBERG; SUAREZ; SHOUSE, 2008; GOLDBERG; CORWIN; SUAREZ, 2005). The $\mathrm{Ads}_{\text {max }}$ increased with an increasing $\mathrm{pH}$, which can be explained by the increased number of active adsorption sites and greater proportion of borate ion $\left[\mathrm{B}(\mathrm{OH})_{4}^{-}\right]$in relation to boric acid $\left[\mathrm{H}_{3} \mathrm{BO}_{3}\right]$.
The maximum $\mathrm{B}$ adsorption estimated by the Langmuir isotherm in the samples without liming was significantly correlated with the exchangeable $\mathrm{Al}$ content $(\mathrm{r}=0.92 ; p<0.05)$ and soluble $\mathrm{B}(\mathrm{r}=0.95$; $p<0.05$ ) (Table 4). In the samples which were limed the maximum B adsorption was significantly correlated with soil $\mathrm{pH}(\mathrm{r}=0.93 ; p<0.05)$, clay content $(\mathrm{r}=0.97 ; p<0.01)$ and iron oxide content $(\mathrm{r}=0.98 ; p<0.01)$ (Table 4).

Table 4. Correlation coefficients of simple linear regression analysis between parameters of Langmuir adsorption isotherms $\left(\mathrm{Ads}_{\max }\right.$ and $\mathrm{K}_{\mathrm{L}}$ ) and adsorption after addition of $2.0 \mathrm{mg} \mathrm{L}^{-1} \mathrm{~B}$ and some soil properties with and without liming.

\begin{tabular}{|c|c|c|c|c|c|c|}
\hline \multirow{2}{*}{ Soil characteristics } & \multicolumn{2}{|c|}{$\begin{array}{l}\text { Maximum adsorption } \\
\left(\mathrm{Ads}_{\max }\right)\end{array}$} & \multicolumn{2}{|c|}{$\begin{array}{c}\text { Bonding energy } \\
\left(\mathrm{K}_{\mathrm{L}}\right)\end{array}$} & \multicolumn{2}{|c|}{$\begin{array}{l}\text { Adsorption after addition of } \\
2.0 \mathrm{mg} \mathrm{B} \mathrm{L}^{-1}\end{array}$} \\
\hline & $\begin{array}{l}\text { Without } \\
\text { liming }\end{array}$ & With liming & $\begin{array}{l}\text { Without } \\
\text { liming }\end{array}$ & $\begin{array}{l}\text { With } \\
\text { liming }\end{array}$ & $\begin{array}{l}\text { Without } \\
\text { liming }\end{array}$ & With liming \\
\hline Soil pH & 0.53 & $-0.93 *$ & -0.67 & -0.27 & 0.21 & $-0.98 * *$ \\
\hline Clay & -0.72 & $0.97 * *$ & $0.96^{*}$ & -0.57 & 0.33 & 0.77 \\
\hline Organic C & 0.54 & 0.43 & 0.45 & $-0.94 *$ & $0.99 * *$ & -0.47 \\
\hline Soluble B & $-0.95 *$ & 0.23 & 0.20 & 0.46 & -0.68 & 0.90 \\
\hline Ex. Al & $-0.92 *$ & 0.16 & 0.13 & 0.53 & -0.73 & 0.89 \\
\hline CEC & 0.89 & 0.42 & 0.39 & 0.28 & -0.53 & 0.91 \\
\hline $\mathrm{SiO}_{2}$ & -0.88 & 0.46 & 0.43 & 0.24 & -0.48 & $0.99 * *$ \\
\hline $\mathrm{Fe}_{2} \mathrm{O}_{3}$ & -0.68 & $0.98 * *$ & $0.97 *$ & -0.61 & 0.38 & 0.74 \\
\hline $\mathrm{Al}_{2} \mathrm{O}_{3}$ & 0.06 & 0.82 & 0.83 & $-0.99 * *$ & $0.93 *$ & 0.02 \\
\hline $\mathrm{Ki}$ & -0.78 & -0.12 & -0.15 & 0.74 & -0.89 & 0.72 \\
\hline
\end{tabular}

Ex. Al: Exchangeable aluminum. CEC: cation exchange capacity. $\mathrm{SiO}_{2}, \mathrm{Fe}_{2} \mathrm{O}_{3}$ and $\mathrm{Al}_{2} \mathrm{O}_{3}$ : silicon, iron and aluminum oxides, respectively. Ki: weathering index calculated by the molar ratio $\mathrm{SiO}_{2} / \mathrm{Al}_{2} \mathrm{O}_{3} \cdot{ }^{*}: p<0.05$. ${ }^{2} *: p<0.01$.

Source: Elaboration of the authors.

The existence of a correlation between the maximum adsorption and $\mathrm{pH}$ was previously reported by Evans (1987) in bit weathered Canadian soils. On the other hand, a lack of correlation between $\mathrm{Ads}_{\max }$ and soil $\mathrm{pH}$ was verified by Azevedo, Faquin and Fernandes (2001) in lowland soils of Minas Gerais, and by Alleoni and Camargo (2000) and Soares, Casagrande and Alleoni (2008) in acric soils of São Paulo State.

Boron adsorption as a function of soil $\mathrm{pH}$ has a maximum value between 8.0 and 9.0 (GOLDBERG,
SUAREZ; SHOUSE, 2008), which may explain the lack of correlation in samples without liming, as presented by the $\mathrm{pH}$ with values below 5.2. In samples with liming, the $\mathrm{pH}$ in water reached values of 7.6 (data not shown), which allowed the existence of a significant correlation with the $\mathrm{Ads}_{\max }$ of B (Table 4). Such evidence shows that the isolated effect of the soil $\mathrm{pH}$ in $\mathrm{B}$ retention seems to be relatively small in acidic soils. Alleoni and Camargo (2000) in studying soils with $\mathrm{pH}$ ranging from 3.5 to 5.5 also had no correlation with B adsorbed in soils 
of São Paulo. Importantly, in the acidic range, B is predominantly in the form of boric acid and not in its ionic form $\mathrm{B}(\mathrm{OH})_{4}^{-}(\mathrm{GOLDBERG}, 1997)$.

The lack of correlation between the B adsorption and cation exchange capacity (CEC) can be explained due to this variable, depending on the content of organic matter and clay, as the CEC cannot theoretically contribute to adsorption of negatively charged species. According to Saltali et al. (2005), among the chemical properties of soil, $\mathrm{pH}$ and clay content are factors that most influence B adsorption. Chaudhary and Shukla (2004) showed that the contents of organic matter and clay and CEC were the chemical attributes that most influenced $\mathrm{B}$ adsorption. However, for soils of the West Indies, Goldberg, Suarez and Shouse (2008) found that CEC was the soil property most associated with the $\mathrm{Ads}_{\text {max }}$ of B.

The lack of significant correlation between B adsorption and organic carbon indicates that the organic matter in lowland soils is probably not one of the most active B adsorption sites. According to Parks and White (1952), $\mathrm{H}^{+}$connected to humic acids at $\mathrm{pH}$ below 6.5 retain a large amount of $\mathrm{B}$ in agricultural soils. This inference is due to the fact that borate anion binding to the organic compounds favors the adsorption mechanism by the formation of boratidol complexes (KEREN; BINGHAM, 1985). Yermiyahu, Keren and Chen (1995) found that organic matter adsorbs more B than the mineral components of soil.

A possible explanation for the lack of the correlation between $\mathrm{B}$ adsorption and organic carbon observed in this study may be due to the low organic carbon content of the soils (Table 2). According to Mezuman and Keren (1981), the effect of organic matter is more pronounced when its levels in the soil are greater than $15 \mathrm{~g} \mathrm{dm}^{-3}$. As such, Sharma et al. (2006) noted an increased B adsorption capacity in the soil after manure application. In soil from northwest India, Arora, Bhardwaj and Sharma
(2002) noted decreased B adsorption following organic matter removal.

There was significant correlation $(\mathrm{r}=0.92 ; \mathrm{p}<0.05)$ between the $\mathrm{Ads}_{\text {max }}$ of $\mathrm{B}$ and the exchangeable $\mathrm{Al}$ content of the soil (Table 4), which shows that the higher the concentration of soil exchangeable $\mathrm{Al}$, the greater the amount of B adsorbed therein. This may occur due to the potential formation and precipitation of aluminum hydroxide with the application of lime. In acid soils, Prodromou (2004) found that the increased B adsorption was closely related to exchangeable $\mathrm{Al}$, precipitated by $\mathrm{CaCO}_{3}$ addition, with a more pronounced effect of freshly precipitated $\mathrm{Al}(\mathrm{OH})_{3}$. Keren and Bingham (1985) found that $\mathrm{Al}$ (hydr)oxide has the ability to adsorb high amounts of $\mathrm{B}$.

Iron oxide $\left(\mathrm{Fe}_{2} \mathrm{O}_{3}\right)$ contents were significantly correlated $(\mathrm{r}=0.98 ; \mathrm{p}<0.01)$ with the $\mathrm{Ads}_{\max }$ of $\mathrm{B}$ (Table 4). This confirms the results obtained by Mezuman and Keren (1981) and Goldberg, Suarez and Shouse (2008), who showed that the higher the content of $\mathrm{Fe}$ (hydr)oxides the higher the maximum $\mathrm{B}$ adsorption. However, the higher correlation coefficients are expected with $\mathrm{Al}$ (hydr)oxide than with $\mathrm{Fe}$, due to the high $\mathrm{B}$ affinity of the $\mathrm{OH}$ groups of $\mathrm{Al}$ (hydr)oxides and the higher specific surface (GOLDBERG, GLAUBIG, 1985). Evidence was only observed for $\mathrm{B}$ adsorption after the addition of $2.0 \mathrm{mg} \mathrm{L}^{-1} \mathrm{~B}$ (Table 4).

The bonding energy of $B$ to the soil $\left(\mathrm{K}_{\mathrm{L}}\right)$ can provide insights into the mechanism most likely involved in B adsorption. The $\mathrm{K}_{\mathrm{L}}$ values estimated for samples without liming were significantly correlated with clay content $(\mathrm{r}=0.96 ; \mathrm{p}<0.01)$ and iron oxides $(\mathrm{r}=0.97 ; \mathrm{p}<0.01)$ (Table 4$)$. The $\mathrm{K}_{\mathrm{L}}$ values obtained after liming indicated that the content of organic carbon and aluminum oxides $\left(\mathrm{Al}_{2} \mathrm{O}_{3}\right)$ were significantly correlated, with correlation coefficients equal to $0.94(\mathrm{p}<0.05)$ and $0.99(\mathrm{p}<0.01)$ respectively (Table 4$)$. 


\section{Conclusions}

The amount of adsorbed B by soils increased with increasing applied concentration.

Liming increased the amount of B adsorbed in Gleissolo Háplico and Plintossolo Háplico soils, although the bonding energy has decreased.

The amount of adsorbed B by Cambissolo Háplico soil was not affected by liming application.

The most important soil properties affecting the $\mathrm{B}$ adsorption in lowland soils were $\mathrm{pH}$, clay content, and exchangeable aluminum and iron oxide contents.

\section{References}

ABREU, M. F.; ABREU, C. A.; ANDRADE, J. C. Determinação de boro em água quente usando aquecimento com microondas. In: RAIJ, B. van; ANDRADE, J. C.; CANTARELLA, H.; QUAGGIO, J. A. (Ed.). Análise química para avaliação da fertilidade de solos tropicais. Campinas: Instituto Agronômico, 2001. p. 231-239.

ALLEONI, L. R. F.; CAMARGO, O. A. Boron adsorption in soils from the State of São Paulo, Brazil. Pesquisa Agropecuária Brasileira, Brasília, v. 35, n. 2, p. 413-421, 2000.

ALLEONI,L.R.F.; CAMARGO,O.A.; CASAGRANDE, J. C. Isotermas de Langmuir e de Freundlich na descrição da adsorção de boro em solos altamente intemperizados. Scientia Agricola, Piracicaba, v. 55, n. 3, p. 379-387, 1998.

ARORA, H.; BHARDWAJ, S. S.; SHARMA, B. D. Effect of organic matter on boron adsorption by some soils of Punjab. Asian Journal of Chemistry, Ghaziabad, v. 14 , n. 2, p. 746-752, 2002.

ARORA, S.; CHAHAL, D. S. Effect of soil properties on boron adsorption and release in arid and semi-arid benchmark soils. Communications in Soil Science and Plant Analysis, London, v. 41, n. 21, p. 2532-2544, 2010.

AZEVEDO, W. R.; FAQUIN, V.; FERNANDES, L. A. Adsorção de boro em solo de várzea do Sul de Minas Gerais. Pesquisa Agropecuária Brasileira, Brasília, v. 36, n. 7, p. 957-964, 2001.

BARROW, N. J. Reactions with variable-charge soils. Dordrecht: Martinus Nijhoff Publishers, 1987. 191 p.
CHAUDHARY, D. R.; SHUKLA, L. M. Boron adsorption and desorption in arid soils of India. Agrochimica, Pacini, v. 48, n. 3-4, p. 141-152, 2004.

CHEN, W. T.; HO, S. B.; LEE, D. Y. Effect of pH on boron adsorption-desorption hysteresis of soils. Soil Science, Baltimore, v. 174, n. 6, p. 330-338, 2009.

COMMUNAR, G.; KEREN, R. Rate limited boron transport in soils: the effect of soil texture and solution pH. Soil Science Society of America Journal, Madison, v. 70, n. 3, p. 882-892, 2006.

EMPRESA BRASILEIRA DE PESQUISA AGROPECUÁRIA - EMBRAPA. Manual de métodos de análise de solo. 2. ed. Rio de Janeiro: Embrapa Solos, 1997. $212 \mathrm{p}$.

. Sistema brasileiro de classificação de solos. 2.ed. Rio de Janeiro: Embrapa Solos, 2006. 306 p.

EVANS, L. J. Retention of boron by agricultural soils from Ontario. Canadian Journal of Soil Science, Ottawa, v. 67, n. 1, p. 33-42, 1987.

GILES, C. H.; SMITH, D.; HUITSON, A. A general treatment and classification of the solute adsorption isotherm. I. Theoretical. Journal of Colloid Interface and Science, Pullman, v. 47, n. 3, p. 755-765, 1974.

GOLDBERG, S. Reactions of boron with soils. Plant and Soil, Dordrechet, v. 193, n. 1-2, v. 35-48, 1997.

GOLDBERG, S.; CORWIN, D. L.; SUAREZ, D. L. Prediction of boron adsorption by field samples of diverse textures. Soil Science Society of America Journal, Madison, v. 69, n. 5, p. 1379-1388, 2005.

GOLDBERG, S.; FORSTER, H. S.; HEICK, E. L. Boron adsorption mechanisms on oxides, clay minerals and soils inferred from ionic strength effects. Soil Science Society of America Journal, Madison, v. 57, n. 3, p. 704708, 1993.

GOLDBERG, S.; GLAUBIG, R. A. Boron adsorption on aluminum and iron oxide minerals. Soil Science Society of America Journal, Madison, v. 49, n. 6, p. 1374-1379, 1985.

GOLDBERG, S.; SUAREZ, D. L.; SHOUSE, P. J. Influence of soil solution salinity on boron adsorption by soils. Soil Science, Baltimore, v. 173, n. 6, p. 368-374, 2008.

HUSSAIN, A.; GHAFOOR, A.; MURTAZA, G. Use of models for phosphorus adsorption on some sodic soils of Punjab. International Journal of Agriculture and Biology, Pakistan, v. 8, n. 2, p. 242-248, 2006. 
KEREN, R.; BINGHAM, F. T. Boron in water, soils, and plants. Advances in Soil Science. New York, v. 1, n. 4, p. 229-276, 1985.

MEZUMAN, U.; KEREN, R. Boron adsorption by soils using a phenomenological adsorption equation. Soil Science Society of America Journal, Madison, v. 45, n. 4, p. 722-726, 1981.

OKAZAKI, E.; CHAO, T. T. Boron adsorption and desorption by some Hawaiian soils. Soil Science, Baltimore, v. 105, n. 5, p. 255-259, 1968.

PARKS, W. L.; WHITE, J. L. Boron retention by clay and humus systems saturated whit various cations. Soil Science Society of America Proceedings, Madison, v. 16, n. 3, p. 298-330, 1952.

PAVAN, M. A.; CORREA, A. E. Reações de equilíbrio solo-boro. Pesquisa Agropecuária Brasileira, Brasília, v. 23, n. 3, p. 261-269, 1988.

PRODROMOU, K. P. Boron adsorption by amorphous $\mathrm{Al}(\mathrm{OH})_{3}$ in the presence of low molecular weight organic acids. Agrochimica, Pacini, v. 48, n. 3-4, p. 172-176, 2004.

ROSOLEM, C. A.; BÍSCARO, T. Adsorção e lixiviação de boro em Latossolo Vermelho-Amarelo. Pesquisa Agropecuária Brasileira, Brasília, v. 42, n. 10, p. 14731478, 2007.

SALTALI, K.; BILGILI, A. V.; TARAKCIOGLU, C.; DURAK, A. Boron adsorption in soils with different characteristics. Asian Journal of Chemistry, Ghaziabad, v. 17, n. 4, p. 2487-2494, 2005.

SHAFIQ, M.; RANJHA, A. M.; YASEEN, M.; MEHDI, S. M.; HANNAN, A. Comparison of Freundlich and Langmuir adsorption equations for boron adsorption on calcareous soils. Journal of Agricultural Research, Washington, v. 46, n. 2, p. 141-148, 2008.
SHARMA, K. R.; SCRIVASTAVA, P. C.; SRIVASTVA, P.; SINGH, V. P. Effect of farmyard manure application on boron adsorption-desorption characteristics of some soils. Chemosphere, Oxford, v. 65, n. 5, p. 769-777, 2006.

SOARES, M. R.; ALLEONI, L. R. F.; CASAGRANDE, J. C. Parâmetros termodinâmicos da reação de adsorção de boro em solos tropicais altamente intemperizados. Química Nova, São Paulo, v. 28, n. 6, p. 1014-1022, 2005.

SOARES, M. R.; CASAGRANDE, J. C.; ALLEONI, L. R. F. Adsorção de boro em solos ácricos em função da variação do pH. Revista Brasileira de Ciência do Solo, Viçosa, v. 32, n. 1, p. 111-120, 2008.

VALladARES, G. S.; PEREIRA, M. G.; ALVES, G. C. Aplicação de duas isotermas de adsorção de boro em solos de baixada do Estado do Rio de Janeiro. Revista Brasileira de Ciência do Solo, Viçosa, v. 22, n. 2, p. 361365, 1998.

VIEZZER, H. P. O.; FRÁGUAS, J. C.; SINSKI, I. Avaliação de adsorção de boro em solo sob vinhedos na Serra Gaúcha. Bragantia, Campinas, v. 54, n. 1, p. $187-$ 191, 1995.

XU, J. M.; WANG, K.; BELL, R. W.; YANG, Y. A.; HUANG, L. Soil boron fractions and their relationship to soil properties. Soil Science Society of America Journal, Madison, v. 65, n. 1, p. 133-138, 2001.

YERMIYAHU, U.; KEREN, R.; CHEN, Y. Boron sorption by soil in the presence of composted organic matter. Soil Science Society of America Journal, Madison, v. 59, n. 2, p. 405-409, 1995. 
